\title{
Ameliorating effect of ascorbic acid on the content of minerals in Eruca sativa Mill. under different air pollutants
}

\author{
Mohammed A. H. Al-Muwayhi ${ }^{1}$, Abdulaziz A. M. Al Sahli ${ }^{2, *}$ \\ ${ }^{1}$ Shaqra University, Faculty of Education, Department of Biology, P.O. Box 33, Shaqra, 11961, Shaqra, Saudi Arabia \\ ${ }^{2}$ King Saud University, College of Science, Botany and Microbiology Department, P.O. Box 2455, Riyadh 11451, Saudi Arabia
}

Email address:

azz1966@hotmail.com (A. A. M. Al Sahli)

\section{To cite this article:}

Mohammed A. H. Al-Muwayhi, Abdulaziz A. M. Al Sahli. Ameliorating Effect of Ascorbic Acid on the Content of Minerals in Eruca Sativa Mill. under Different Air Pollutants. Journal of Food and Nutrition Sciences. Special Issue: Food Processing and Food Quality.

Vol. 3, No. 1-2, 2015, pp. 161-164. doi: 10.11648/j.jfns.s.2015030102.41

\begin{abstract}
The experiment was conducted to study the effect of different air pollution (ozone $\mathrm{O}_{3}$, sulfur dioxide $\mathrm{SO}_{2}$, and nitrogen dioxide $\mathrm{NO}_{2}$ gases) on Eruca sativa Mill. at three locations in Riyadh city, KSA. During the study, we found that the concentrations of gases were increasing gradually at the study sites. Ozone concentration and sulfur dioxide at the cement factory area site were $91 \mathrm{ppb}$ and $29 \mathrm{ppb}$, respectively, as well as concentration of nitrogen dioxide was $29 \mathrm{ppb}$ at the first industrial area and cement factory area. The present experiment showed that these three pollutants gases caused a significant effect on the concentration of some mineral elements. Interestingly, the plants treated with ascorbic acid showed maximum content of mineral nutrients phosphorus $(\mathrm{P})$, potassium $(\mathrm{K})$, nitrogen $(\mathrm{N})$, cupper $(\mathrm{Cu})$, iron $(\mathrm{Fe})$, zinc $(\mathrm{Zn})$ and manganese (Mn). The study aims to identify concentrations of ozone gas, sulfur dioxide and nitrogen dioxide in three different locations in Riyadh and determine its harmful effects on the concentration of some metal elements, and study the effect of ascorbic acid to reduce the adverse impact of these gases in Eruca sativa Mill.
\end{abstract}

Keywords: Ozone, Sulfur, Nitrogen Dioxide, Ascorbic Acid, Eruca sativa

\section{Introduction}

Toxic air pollutants such as ozone $\left(\mathrm{O}_{3}\right)$, sulfur dioxide $\left(\mathrm{SO}_{2}\right)$, nitrogen dioxide $\left(\mathrm{NO}_{2}\right)$ enter into the atmosphere at increasing rates due to the increasing population and industrialization. An increasing concentration of air pollutants limits the growth and developmental of agricultural crops. High concentration of air pollutants alters air quality and affects people, flora and funa (Govindaraju, Ganeshkumar, Muthukumaran \& Visvanathan, 2012). Plants are generally more affected than animals by air pollution, as they constantly take up atmospheric gasses. Of all plant parts, the leaf is the most sensitive part to the air pollutants (Meerabai, Venkata Ramana, \& Rasheed, 2012). Ozone enters into the plant through stomata where decompose in cell wall water and then interacts directly with the plasma membrane through decomposition process (Ozonolysis) or turns to the forms of oxygen active. These interactions change cellular components that may lead to the acceleration of senescence or cell death (Logan \& Naidu, 2002).Mineral nutrients are essential for plants to complete their life cycle.
Plant mineral nutrients constitute a major component of many metabolic active compounds such proteins, hormones, chlorophyll, vitamins and enzymes. Most studies about ozone effects on plant nutrition were on trees, so the available information on the response of trees to ozone effect, probably cannot be generalized to herbaceous plants, for which information is scarce (Fangmeier, De Temmerman, Black, Persson, \& Vorne, 2002). There are few studies available on this subject. Response of plants to pollutants differs markedly, some are highly sensitive and others hardy and tolerant to pollutants (Singh \& Rao 1983; Shannigrahi \& Agrawal, 1996; Chaulya, Chakraborty, \& Singh, 2001).

Ascorbic acid (ASA) is an important growth regulator that affects many physiologic processes (Hathout, 1995; Gonzlez, Steffen, \& Lynch, 1998). It is well established that ascorbic acid plays a key role in photosynthesis as an enzyme cofactor (including synthesis of ethylene, gibberellins and anthocyanins) and in control of cell growth and cell expansion and in resistance to environmental stresses (Smirnoff \& Wheeler, 2000).

In recent decades Riyadh has witnessed a big industrial 
development that had a negative impact on the environment. The increase in population, which exceeded four million, has significant impact on increasing the number of transportation and need for energy and various services, therefor increased fuel consumption and burne leading to excessive increase in the rates of emission of pollutants that have a negative impact on the plant.

Rocket (E. sativa Mill) is an annual herb belonging to the Brassicaceae family, its spicy hot flavor; rocket is very important crop and use in salads for flavor and in large variety of meals. According to D'Antuono, Elementi and Neri (2009) and Barillari et al. (2005), rocket contains a number of health promoting agents including carotenoids, vitamin $\mathrm{C}$, fibers, flavonoids, and glucosinolates (GLs). The aim of our research was to measure the concentrations of ozone gas, sulfur dioxide and nitrogen dioxide at three different locations in Riyadh city and to determine its harmful effects on the concentration of some mineral elements in E. sativa Mill. and the role of ascorbic acid to reduce the impact of these gases.

\section{Materials and Methods}

\subsection{Sites of Study}

Three different sites were selected (King Saud University, the first industrial area and cement factory area) to study in Riyadh city. At the beginning of the experiment, seeds of $E$. sativa Mill. were sown outdoors in plastic pots $25 \mathrm{~cm}$ containing sandy loam soil and added a fungicide to prevent of fungus. Three pots were taken for each concentration. We maintained three plants in each pot throughout the experiment. When the plant was at the stage of 2-4 true leaves, pots were shifted to the study sites for study. Plants in the study sites were irrigated once every 15 days with following concentrations of ascorbic acid (zero, 50,100, 200, 300 and $400 \mathrm{mg} / \mathrm{L}$ ).

\subsection{Agriculture}

Seeds of Eruca sativa Mill. were planted outdoors in plastic pots $20 \mathrm{~cm}$ in sandy loam soil sterile 1:1 added a fungicide to prevent of fungus, three pots was put for each concentration, each pot contains three seeds have washed and sown on May 10, 2011, and left even completed the initial leaves growth, then transferred to the study sites.

\subsection{Treatment}

Plants in the study sites were irrigated once every 15 days with following concentrations of ascorbic acid (zero, 50,100, 200, 300, $400 \mathrm{mg} / \mathrm{L}$ ).

\subsection{Measurements}

The concentration of ozone, sulfur dioxide and nitrogen dioxide were recorded daily at the study sites using multi-gas analyzer (Gray Wolf, Sweden), and then calculated the average. Plant samples were taken from the leaves of $E$. sativa Mill. at the late vegetative growth before flowering stage. Estimation of phosphorus was done using (Spectrophotometer-LKB-4050) (Murphy \& Riley, 1962). Potassium content was measured using Flame Photometer (Allen, 1989). Organic carbon was estimated according to Tandon (1993). Estimation of nitrogen was done using microkjeldahl (Jones, 1991). Elements (copper, iron, zinc, and manganese) were done using atomic absorption spectroscopy according to Stewart (1989).

\subsection{Statistical Analysis}

The experiment was Completely Randomized Design with three replicates. The data were analyzed statistically by analysis of variance according to Gomez and Gomez (1984). For the F-test, the error due to replicates was also determined. When the F-value was found to be significant at 5\% level of probability, the least significant difference (LSD) was calculated.

\section{Results}

\subsection{The Concentrations of Gases (Ozone, Sulfur Dioxide and Nitrogen Dioxide) at the Sites of Study}

The results in Table (1) show that the concentration of gases was found different at these sites. We noted that the concentrations of $\left(\mathrm{O}_{3}, \mathrm{SO}_{2}\right.$, and $\left.\mathrm{NO}_{2}\right)$ at the site of the King Saud University were less than in the first industrial area, and cement factory area. Where $\mathrm{O}_{3}$ concentration at the site of the King Saud University, the first industrial area and the cement factory area during the month of March was 60, 87 and 91 ppb respectively. The concentration of $\mathrm{SO}_{2}$ at the site of the King Saud University, the first industrial area and the cement factory area during the month of March was recorded 12, 26 and $25 \mathrm{ppb}$ respectively. In addition, the concentration of $\mathrm{NO}_{2}$ at the site of the King Saud University, the first industrial area and the cement factory area during the month of March was 11,29 and $27 \mathrm{ppb}$.

\subsection{Mineral Elements Content in Plants}

The results in Table (2) reveal that the gases $\left(\mathrm{O}_{3}, \mathrm{SO}_{2}\right.$, and $\mathrm{NO}_{2}$ ) had a significant effect on mineral elements in E. sativa Mill grown at all sites. However, their effects were found different among the plants grown at three sites. In the present study we noticed a general trend that the content of mineral elements in plant grown at these sites increased with increasing treatments of ascorbic acid. The plants grown at the kind Saud University site showed maximum content of mineral nutrient in comparison to those plants grown at sites of the first industrial area and the cement factory area. Application of $400 \mathrm{mg} / \mathrm{L}$ of ascorbic acid exhibited 4.35, $3.85,3.31 \mathrm{mg} / \mathrm{L}$ of phosphorus, and $0.92,0.57,0.47 \%$ of nitrogen, and $0.37,0.31,0.27 \mathrm{mg} / \mathrm{L}$ of manganese in plants grown at the site of King Saud University, the first industrial area and the cement factory area, respectively. 
Table 1. Average of monthly reading for ozone, sulphur dioxide and nitrogen dioxide at study sites

\begin{tabular}{|c|c|c|c|c|}
\hline Location & Months & \multicolumn{3}{|c|}{ Concentration Average (ppb) } \\
\hline \multirow{2}{*}{ King Saud Uni. } & Jan. & 55 & 10 & 12 \\
\hline & Mar. & 60 & 12 & 11 \\
\hline \multirow{2}{*}{ First Industrial City } & Jan. & 72 & 24 & 26 \\
\hline & Mar. & 87 & 26 & 29 \\
\hline \multirow{3}{*}{ Cement Factory } & Jan. & 78 & 27 & 24 \\
\hline & Feb. & 83 & 29 & 29 \\
\hline & Mar. & 91 & 25 & 27 \\
\hline \multicolumn{2}{|c|}{ Limit global air pollution (ppb) (CASTNET, 2004) } & $30-25$ & 30 & 35 \\
\hline
\end{tabular}

Table 2. Effect of gases (ozone, sulphur dioxide, nitrogen dioxide and Ascorbic acid) on the content of mineral elements in E. sativa Mill.

\begin{tabular}{|c|c|c|c|c|c|c|c|c|c|c|}
\hline Location & Treatm & & $P(\mathrm{mg} / \mathrm{L})$ & $K(\mathrm{mg} / \mathrm{L})$ & C (\%) & N (\%) & $\mathrm{Cu}(\mathrm{mg} / \mathrm{L})$ & $\mathrm{Fe}(\mathrm{mg} / \mathrm{L})$ & $\mathrm{Zn}(\mathrm{mg} / \mathrm{L})$ & $\operatorname{Mn}(\mathrm{mg} / \mathrm{L})$ \\
\hline \multirow{4}{*}{$\begin{array}{l}\text { King Saud } \\
\text { Uni. }\end{array}$} & \multirow{5}{*}{$\begin{array}{l}\text { ASA } \\
(\mathrm{mg} / \mathrm{L})\end{array}$} & 0 & 3.55 & 153 & 27.49 & 0.45 & 0.12 & 4.03 & 0.33 & 0.23 \\
\hline & & 50 & 3.61 & 154 & 27.75 & 0.49 & 0.17 & 4.34 & 0.34 & 0.29 \\
\hline & & 200 & 4.21 & 158 & 30.92 & 0.62 & 0.26 & 4.82 & 0.37 & 0.34 \\
\hline & & 300 & 4.32 & 161 & 31.07 & 0.78 & 0.28 & 5.13 & 0.42 & 0.35 \\
\hline \multirow{6}{*}{$\begin{array}{l}\text { Cement } \\
\text { Factory }\end{array}$} & & 400 & 4.35 & 162 & 31.14 & 0.92 & 0.28 & 5.24 & 0.43 & 0.37 \\
\hline & \multirow{5}{*}{$\begin{array}{l}\text { ASA } \\
(\mathrm{mg} / \mathrm{L})\end{array}$} & 0 & 2.25 & 148 & 25.23 & 0.32 & 0.09 & 3.54 & 0.30 & 0.20 \\
\hline & & 100 & 3.11 & 150 & 25.66 & 0.41 & 0.13 & 4.03 & 0.31 & 0.25 \\
\hline & & 200 & 3.51 & 151 & 27.52 & 0.42 & 0.17 & 4.07 & 0.31 & 0.28 \\
\hline & & 300 & 3.62 & 153 & 27.22 & 0.51 & 0.19 & 4.54 & 0.32 & 0.28 \\
\hline & & 400 & 3.85 & 155 & 28.21 & 0.57 & 0.19 & 4.67 & 0.33 & 0.31 \\
\hline \multirow{2}{*}{$\begin{array}{l}\text { First } \\
\text { Industrial } \\
\text { City }\end{array}$} & \multirow{2}{*}{$\begin{array}{l}\text { ASA } \\
(\mathrm{mg} / \mathrm{L})\end{array}$} & 0 & 1.44 & 146 & 23.43 & 0.30 & 0.07 & 3.01 & 0.28 & 0.16 \\
\hline & & 50 & 2.23 & 146 & 23.47 & 0.31 & 0.07 & 3.03 & 0.29 & 0.19 \\
\hline LSD at 0.05 & & & 0.445 & 3.32 & 0.028 & 0.028 & 0.030 & 0.030 & 0.033 & 0.029 \\
\hline
\end{tabular}

\section{Discussion}

The results showed that ozone concentration in the three sites under the study exceeded from the allowable universally limit (25-30 ppb).The site of the King Saud University scored less concentration compared with other two sites (the first industrial area and the cement factory area). While the concentration of sulfur dioxide and nitrogen dioxide did not exceed from the allowable global limit of air pollution (CASTNET, 2004; Fenger, 2009). A difference in leaves content of some mineral elements in plants grown at these sites was found because of different concentration of $\mathrm{O} 3$ at three sites. Plants grown at the King Saud University site (less content of O3.Table1) showed maximum content of mineral elements as compared to the plants grown at the site of the first industrial area and the cement factory area (Table 1 and 2). Were evident in the study sites, the differences were statistically significant; low proportion of mineral elements in plant leaves in the first industrial area and a cement factory area compared with the plants at King Saud University site may be due to an increase ozone concentration. This result is consistent with the findings of Fangmeier, De Temmerman, Black, Persson and Vorne (2002) and Schier, McQuattie and Jensen (1990), which pointed out that exposure to high ozone leads to shifts or changes in the concentration of elements within the plant tissue.In the present study we found that application of ascorbic acid showed surprising effect on mineral elements content of plants grown in at these study sites. Application of ascorbic acid increased all mineral elements content in plants grown at all sites (Table 2). As we know that ascorbic acid is an important component of plants and its concentration reaches of over $20 \mathrm{mM}$ in chloroplast and occurs in cell was. Therefore, the concentration of mineral elements in leaf increased may be due to antioxidative properties of ascorbic acid that efficiently scavenges toxic free radicals and other reactive oxygen species generated in cell due to zone (Arrigoni \& Tullio, 2002; Smirnoff, 1996). Also, Foyer (1993) reported that 
ascorbic acid plays a role in the physiological processes in the plant, small concentrations of it regulates plant growth.

\section{Conclusions}

This investigation has demonstrated that the concentration of air pollutants $\left(\mathrm{O}_{3}, \mathrm{SO}_{2}\right.$, and $\left.\mathrm{NO}_{2}\right)$ in the study sites has increased, average concentration of ozone $\mathrm{O}_{3}$ per month was higher than allowable limit, while concentration of $\mathrm{SO}_{2}$, and $\mathrm{NO}_{2}$ did not exceed globally limit allowable. The air pollutants in the study sites had a significant effect on the mineral content in the plants. The content of mineral elements increased with increasing concentration ascorbic acid.

\section{Acknowledgements}

The authors acknowledge and appreciate the King Saud University represented in Research Center of Science College, which funded this work.

\section{References}

[1] Allen, S. E. (1989). Chemical analysis of ecological methods. $\left(2^{\text {nd }}\right.$ ed.). Oxford: Blackwell.

[2] Arrigoni, O., \& De Tullio, M. C. (2002). Ascorbic acid: much more than just an antioxidant. Biochimica et Biophysica Acta, $1569,1-9$.

[3] Barillari, J., Canistro, D., Paolini, M., Ferroni, F., Pedulli, G.F., Iori, R., \& Valgimigli, L. (2005). Direct Antioxidant Activity of Purified Glucoerucin, the Dietary Secondary Metabolite Contained in Rocket (E. sativa Mill.) Seeds and Sprouts. Journal of Agricultural and Food Chemistry, 53, 2475-2482.

[4] CASTNET (Clean Air Status and Trends Network), (2004). Annual Report. Prepared for: U.S. Environmental Protection Agency; Office of Air and Radiation; Clean Air Markets Division, Washington, D.C, and EPA Contract No. EP-W-09028.

[5] Chaulya, S. K., Chakraborty, M. K., \& Singh, R. S. (2001). Air pollution modeling for a proposed limestone quarry. Water, Air and Soil Pollution, 126, 171-191.

[6] D'Antuono, L. F., Elementi, S., \& Neri, R. (2009). Exploring new potential health-promoting vegetables: glucosinolates and sensory attributes of rocket salads and related Diplotaxis and E. species. Journal of the Science of Food and Agriculture, 89, $713-722$.

[7] Fangmeier, A., De Temmerman, L., Black, C., Persson, K., \& Vorne, V. (2002). Effects of elevated $\mathrm{CO}_{2}$ and/or ozone on nutrient content and uptake of potatoes. European Journal of Agronomy, 17, 353-368.

[8] Fenger, J. (2009). Air pollution in the last 50 years - From local to global. Atmospheric Environment. 43, 13-22.
[9] Foyer C. H. (1993). Ascorbic acid. In R. G. Alscher, \& J. L. Hess (Eds.), Antioxidants in higher plants. (pp. 31-58). Boca Raton: CRC Press.

[10] Gomez, K. A., \& Gomez, A. A. (1984). Statistical procedures for agricultural research. (2nd Ed.), (pp. 13-175). London: John Wiley and sons, Inc.

[11] Gonzlez, A., Steffen, K. L., \& Lynch, J. P. (1998). Light and excess manganese. Implications for Oxidative Stress in Common Bean. Plant Physiology, 118, 493-504.

[12] Govindaraju, M., Ganeshkumar R. S., Muthukumaran V. R., \& Visvanathan, P. (2012). Identification and evaluation of airpollution-tolerant plants around lignite-based thermal power station for greenbelt development. Environmental Science and Pollution Research,19, 1210-1223.

[13] Hathout, T. A. (1995). Diverse effects of uniconazole and nicotinamide on germination, growth, endogenous hormones and some enzymic activities of peas. Egyptian Journal of Physiological Sciences, 19, 77-95.

[14] Jones, Jr. (1991). Kjeldahl method for nitrogen determination. Athens: Micro-Macro Publishing Inc.

[15] Logan, S. P., \& Naidu, S. L. (2002). Effects of oxidants at the biochemical, cell and physiological levels, with particular reference to ozone. In: J. N. B. Bell, \& M. Treshow (Eds.), Air pollut. and plant life, pp. 69-88.

[16] Meerabai, G., Venkata Ramana, C. \& Rasheed M. (2012). Effect of air pollutants on leaves of pigeon pea, a pulse crop of Fabaceae growing in the vicinity of a silicon industry. World Rural Observations, 4, 19-21.

[17] Murphy, J., \& Riley J. (1962). A modified single solution for the determination of phosphate in natural waters. Analytica Chimica Acta, 27, 31-36.

[18] Schier, G. A., McQuattie, C. J. \& Jensen, K. F. (1990). Effect of ozone and aluminum on pitch pine (Pinusrigida) seedlings: growth and nutrient relations. Canadian Journal of Forest Research, 20, 1714-1719.

[19] Shannigrahi, A. S., \& Agrawal, K. M. (1996). An overview on optimal greenbelt development for industrial project. Indian Journal of Environmental Protection, 17, 253-261.

[20] Singh, S. K., \& Rao, D. N. (1983). Evaluation of plants for their tolerance to air pollution. In: Proceedings Symposium on Air Pollution Control, (Indian Association for Air Pollution Control, New Delhi, India). 1, 218-224.

[21] Smirnoff, N. (1996). The function and metabolism of ascorbic acid in plants. Annals of Botany, 78, 661-669.

[22] Smirnoff, N., \& Wheeler, G. L. (2000). Ascorbic Acid in Plants: Biosynthesis and Function. Critical Reviews in Biochemistry and Molecular Biology. 35, 291-314.

[23] Stewart, E. A. (1989). Chemical analysis of ecological materials. Oxford: Blackwell Scientific publications.

[24] Tandon, H. L. S. (1993). Methods of analysis of soils, plant, water, fertilizers. Fertilizer development and consultation organization, New Delhi, India. 